\title{
CARGILL G. KNOTT, D.Sc., LL.D., F.R.S.
}

\author{
By Dr Archibald Milne.
}

Hardly had Edinburgh University entered upon its present academic year than it was deprived by the hand of Death of the services of CARGILL G. KNotr, Reader in Applied Mathematics. The news of his death came as a great shock to all his friends, as there was no illness or other sign which might have foreshadowed the summons that was coming to him. Apparently in his usual robust health, he was engaged in his various duties until the very end, which came to him with startling suddenness.

His multiple activities as University Lecturer, as official adviser of candidates in Edinburgh University reading for honours in Mathematics and Natural Philosophy, as General Secretary of the Royal Society of Edinburgh, as well as his own research investigations and other work of a less public nature, had linked him up with many associations. Amongst these was the Edinburgh Mathematical Society, of which he was one of the founders, and with which he maintained an intimate connection throughout its existence, being, in fact, at the time of his death engaged upon a paper which was to have been read at the first meeting of the Society in the session 1922-23.

In the early eighties of last century there was a remarkable vivifying of mathematics in secondary schools throughout the country. This was primarily due to the influence of Chrystal, whose brilliant work at the University aroused tremendous interest amongst the teachers whose pupils ultimately entered the University. One result of this awakened interest was the formation of the Edinburgh Mathematical Society, and it is in this connection that Knott's name will always be remembered among us. Fully conscious of the moribund condition of mathematics hitherto, and of the possibilities that lay before it in the schools through the impetus given to it by Chrystal and others, Knott, with one or two kindred enthusiasts, sought to consolidate and to render permanent that work by founding the Mathematical Society which was to be a ready means of co-operation between the schools on the one hand and the University on the other. The methodology of mathematical teaching, whereby the best means of presenting the subject to school-pupils might be attained, was to form one of the essential aims of the Society. It is not too much to say that the high standard of mathematics prevailing in our schools to-day is due in no small measure to the Society, and thereby must largely be put to the credit of Knott. Taking upon himself 
the two offices of Secretary and Treasurer, he did a great amount of the spade-work that is inevitable in the early years of any organisation. In enrolling new members, in arranging programmes for meetings, and in countless other ways, he enthusiistically and energetically worked on behalf of the young Society. When he returned to this country from Japan he at once resumed attendance at its meetings, and became VicePresident in 1892-3 - being appointed President in the following year.

Due, undoubtedly, to the influence of Tait, Knott was essentially a physicist, but, as I have endeavoured to show, he had a very real and abiding interest in pure mathematics. The developments of Hamilton's Quaternions that were made by Tait appealed strongly to him, and to a greater extent, I think, than anyone else, did Knott pursue the study of quaternionic analysis. His work on the mathematical theory of earthquakes is also well known, while frequently he contributed papers to the Society on various mathematical topics.

To-day, when the boud of association between the schools and the Universities is so intimate, it is somewhat difficult to realise the adverse conditions of forty years ago, but the difficulty of that realisation must not make us forget that the present conditions were rendered possible and were eventually brought to pass by the devoted labours of a band of pioneers, amongst whom none workẹd more unremittingly and none could more deservingly view the success of the Society as being the fruit of those early labours, than he whose loss we mourn to-day. 